\title{
A Rasch analysis of the Entrepreneurship education and students of the creative economy in Indonesia
}

\author{
Denada Faraswacyen L. Gaol ${ }^{1}$, Erna Maulina ${ }^{2}$, Asep Miftahuddin ${ }^{3}$, Muhamad Mutofid ${ }^{4}$, \\ Dindin Mohamad Syafarudin ${ }^{5}$ \\ Faculty of Social and Political Science, Department of Business Administration, Universitas \\ Padjadjaran ${ }^{1,2,3,4,5}$ \\ \{denada18001@mail.unpad.ac.id ${ }^{1}$, erna.maulina@unpad.ac.id ${ }^{2}$, \\ asep17012@mail.unpad.ac.id ${ }^{3}$,Mutofid@yahoo.com ${ }^{4}$, dewo.marco88@gmail.com $\left.{ }^{5}\right\}$
}

\begin{abstract}
The research aims to identify entrepreneurial spirit as a driver of the creative economy in students. This study uses a quantitative approach, explanatory, descriptive methods, primary and secondary data types, data collection techniques through questionnaires and literature studies, Rasch Model data analysis techniques. The results of the study show that the respondents already have good knowledge of entrepreneurship which is shown by the level of understanding of each item statement so that it can be concluded that the entrepreneurship course is properly included in the lecture. Entrepreneurial status is still doubtful to become a profession with pride higher than other professions, more attractive entrepreneurship is done conventionally rather than online which is certainly very contradictory to the scientific background that is closely related to the use of online media so that it needs to provide knowledge and increased insight into the benefits of using online media as a means of supporting entrepreneurs. The last is the low entrepreneurial talent of students so that it is still very necessary to provide information that can foster interest in starting entrepreneurs such as through research, learning.
\end{abstract}

Keywords: creative economy, entrepreneurship, students

\section{Introduction}

Changing the map of the global economy puts creativity as the main capital in facing global challenges. In the perspective of globalization, competitiveness is the key factor for success and survival. This competitiveness appears not only in the form of products based on quantity but also no less important in terms of quality. The quality of these products can be obtained through brand image or creating innovative products that have added value compared to other products. Therefore high creativity is needed to create innovative products and be globally competitive[1].

The Creative economy can be a proponent of new industry and become an accelerator or accelerator existing economic activity, this means that it is very clear that the actors, workers, and consumers also contribute to economic growth. The government greatly appreciates and thanks to the creative economic actors[2]. With a variety of products, they provide a touch of creative and technological innovations that boost added value. The perpetrators are young. 
Educational institutions such as universities as intelligent and creative beings forming function are to provide information and insight related to entrepreneurship, especially about the use of technology to students. Can realize that the learning system and curriculum that are memorized the course, will not have an impact on something that generated a protege in the world of work and the real world[3]. The real struggle is how one can cultivate creativity and maximizing the potential of creativity in the face and solve a problem.

As the first private higher education institution in Indonesia that is engaged in information technology and has a leading study program at FTI and FIKOM, Budi Luhur University is encouraging its alumni not only to become job seekers but also to become creators or creators of jobs that are by their science. Students can see market opportunities that are developing now towards creative industries that utilize information and communication technology. The ability to see these market opportunities is supported by curiosity and an entrepreneurial spirit to take advantage of entrepreneurial abilities and interests. At present entrepreneurial activities driven by young people tend to be towards startup which is closely related to the use of information and communication technology. Based on this background, this study aims to identify the spirit of student entrepreneurship through the use of information and communication technology. The survey was conducted by distributing questionnaires to FTI, FEB, and FIKOM students as respondents, then processing data and analysis using the Rasch Model[4].

\section{Literature review}

\subsection{Information and communication technology}

New Media or online media is defined as a product of technology-mediated communication shared with digital computers[5]. According to Lev Manovich in the book The Language of New Media, new media changes all cultural and cultural theories into 'open source.'

This can open culture from techniques, habits, forms, and concepts which ultimately the cultural effects of computerization are most promising. According to [6], the reasons for the development of the internet can develop rapidly are (1) Costs, (2) Various forms of promotion, (3) Personalization, (4) Timeless, (5) Digital Branding, (6) Location based on places far.

\subsection{Entrepreneurial spirit}

An entrepreneur is someone who has certain souls and abilities in creating and innovating. He is someone who can create something new and different or creative and innovative abilities These creative and innovative abilities are clearly reflected in the willingness and ability to start doing business (start-up), the ability to do something new (creative), willingness and ability to look for opportunities, ability, and courage to bear risk (risk-bearing ) and the ability to develop ideas and use available resources[7].

This willingness and ability are needed especially for 1 . Perform a new technique; 2. Produce new products or services (the new product or new service); 3 . Producing new valueadded; 4 and initiating a new business that refers to the market; and 5. Develop a new organization (the new organization). 


\subsection{Creative Economy}

The emergence of a knowledge-based economy that starts from the paradigm of the creative industry that surfaced begins with the rapid development of the internet, science, and technology so that this encourages the changing dynamics of mapping the direction of the industry globally to form a creative economy.

The concept of creative economy is an economic activity with input and output in the form of ideas, whose forming role is controlled by intellectual property law (patents, copyrights, brands, royalties, and designs)[8]. The creative economy consists of professional groups. Those who are in the creative industry contribute to the forefront of innovation so that the creative economy can be said to be a system of supply and demand transactions sourced from the economic activities of the creative industry[9]. The creative industry focuses on value creation through the power of creativity. Ideas and ideas are the main keys in the creative industry, so this idea becomes a key asset.

\section{Method}

This study uses a quantitative approach, namely quantifying respondents answers on a nominal scale and Likert rating then inputting the statistical data into the parent table or tabulation to be processed with the Winstep software from the Rasch Model[10]. The research method used is descriptive explanatory which describes the characteristics of respondents and the quality of statement items developed from each variable and then explained the results of research based winstep software[11].

The data sources in this study are respondents in the form of students from three faculties who are directly related to science with the creative industry and entrepreneurs namely FIKOM, FEB, and FTI. The number of respondents is 100 people with purposive sampling technique because it sets the criteria for students from three faculties who are closely related scientifically with the creative industry and who have taken entrepreneurial courses.

Data analysis techniques using Rasch Model is by measuring and analyzing the quality of statements developed from each research variable and measuring the quality of respondents based on answers to the statements given[10][12]. Next, discuss and conclude the results of the research.

\section{Result and discussion}

Research instrument questionnaire consists of two parts, namely the respondent data that contain sex, age, GPA, and the school of origin, and a statement as much as 20 developed from variable economic research creatively and entrepreneurial. Based on the data generated using the Rasch model \pm 1:23 Pearson measure means an average value of 0.0 indicates a tendency logit respondent agreed to the statement on various items.

From the results of this study indicate that the preparation of statements in a language that is straightforward and easy to understand by the students' catching ability as respondents or tends to consider easily each statement given. Based on the explanation in the Rasch Analysis Model that the preparation of statements in the questionnaire must start from the easiest statement to be approved to the most difficult statement to be approved. For example, statement 1 "You get an Entrepreneurship course" to conjecture to the statement 20 of the 
most difficult to approve "You are more likely to get a partner if you become a young entrepreneur."

In the formulation of these statements are not arranged in all positive sentences but rather a proportional combination with negative sentences to test the accuracy and accuracy of the respondents in reading the statement. Preparation of statements is also not a new and difficult thing for respondents because creative economic variables and entrepreneurship are closely related to the scientific background of students in the faculties of communication sciences, economics and business faculties, and information technology faculties.

Some practice courses that support the creation of creative ideas also intersect with creative industries such as creative thinking, computer applications, documentary features, technique announcing, advertising production, creative concepts in advertising, photography, event management, graphic design, digital imaging, photography, etc.

Reliability in this study is the level of the constancy of people (respondents) with items (statements), namely the extent to which the interaction of people (respondents) with items (statements) can be trusted to produce a fixed score, relatively unchanged even if tested in different situations. Cronbach Alpha of 0.92 means that the reliability of the interaction of the person (respondent) with the item (statement) falls into the excellent category. From the results of these calculations show the reliability of statements or the consistency of statements to be measured in different conditions and times will remain reliable or reliable as a measure of perceptions, attitudes, and opinions of respondents related to the creative economy and entrepreneurship.

The number of logit items from the mean and SD is $0.95+0.35=1.30$. Then items with infit value $>1.30$ are N20 of $1.95, \mathrm{~N} 10$ is 1.45 , and N5 is 1.32 . This means that statements 20 , 10 , and 5 are items that misfit or instrument statements of creative and entrepreneurial economics that are most difficult to be approved by students, namely the statement "It is easier to get a partner if you are a young entrepreneur" (P20) "(P10), and" You have strong business intuition/talent "(P5). Of the three most difficult statements to be approved by the students explained that entrepreneurial status has not become a profession of interest to raise social status or pride for students because it is still considered difficult to get a life partner in the future. Therefore it is necessary to follow up from various parties to socialize that being an entrepreneur has a promising future, for example by making a successful entrepreneur figure as a role model that is worthy of being a role model to foster entrepreneurial talent. Efforts to present young entrepreneurs or start-ups to become resource persons or seminar speakers at the campus so they can open insight and share information with students.

Furthermore, entrepreneurship easier to do through online media is also difficult to approve. This means that the mindset of students is still confined to conventional methods or old-fashioned entrepreneurs. Of course, this is very contrary to the development of IT, scientific background and daily activities of students who generally use online media. From this information can be formulated as a way to teach the use of online media to give birth to creative ideas as a basic capital to start creative industries and entrepreneurs. Online media can be used as a means of producing ideas, formulating into products or services of economic value, to the means of promoting creative products or services to market share, and so on. For this reason, it is necessary to make a clear e-commerce roadmap, covering logistical, funding, broadband issues that reach remote areas, and human resources in the context of the digital economy.

Based on Person Measure obtained the value of logit person for respondent number 01 female, age $>20$ years, GPA $>3$, school origin from the country has a score of +5.24 logit means the tendency of entrepreneurial talent is highest compared to other respondents, while 
respondents number 10 male, age $<20$ years, GPA $<3$, origin of school from the private sector, has a logit score of -0.74 which is the respondent who answers a lot in the direction of disagreement from the entrepreneurial item. From the presentation, it can be concluded that female students aged $>20$ years, GPA $>3$, the origin of school from the country has the most entrepreneurial spirit among other student respondents, so perseverance and enthusiasm need to be fostered by continuing to develop courses that are capable of generating creative ideas.

Based on the variable maps, it is found that the statement that is difficult to approve is P11, that is, you feel you have the capital to start entrepreneurship, meaning that students are still thinking that starting a business requires capital in the form of funds first. This shows a false understanding that the initial capital is creative ideas which are determining factors whether a business can be started or not. Finally, the easiest item to approve is P16, that is, you feel proud to have income from an entrepreneur. The answer to this statement is considered easy and interesting because it deals with the results obtained from entrepreneurship, namely money.

Based on the overall results of these studies can be obtained some interesting information, namely students who have a solid scientific background with IT devices and their daily use of digital devices turned out to be not interested in using online media as a means of supporting the birth of creative ideas. Their tendency to assume that they do not have entrepreneurial talent but feel proud if they have income from entrepreneurs. The answer is very ironic and it can be concluded that students lack perseverance even though they are supported by knowledge, facilities, and environments that are very close to creative ideas, and tend to be instant or result oriented because they feel proud to have income from entrepreneurship when they don't have the spirit to start business or undergo the entrepreneurial process.

\section{Conclusion}

Based on the variable maps, it is found that the item that is difficult to approve is N11, that is, you feel you have the capital to start an entrepreneur and the easiest item to approve is N16, that is, you feel proud to have income from entrepreneurs. Based on the Rasch Model data, it can be explained that the respondents already have good knowledge of entrepreneurship.

This is indicated by the level of understanding of each item statement so that it can be concluded that entrepreneurship courses are appropriately incorporated into lectures and are very useful for the knowledge and insights of students in entrepreneurship. The selection of students as respondents is considered very good because it is a young generation who has the spirit, enthusiasm, and creative energy to start an entrepreneur. Creative entrepreneurship is closely related to young people who have many ideas to develop, try new things especially those related to creative work in the fields of application and game developers, architecture, interior design, visual communication design, product design, animated films and videos, photography, music, advertising, television, and radio. These fields are often pioneered and mobilized by young entrepreneurs.

The quality of statements included in the category is sufficiently meaningful for the next study to develop items from the entrepreneurial variable to be more detailed and easily understood by respondents. This is also indicated by statements 20, 10 and 5, which are easier for you to get a partner if you are a young entrepreneur, entrepreneurship is easier to do through online media, and you have strong business entrepreneurship. The three statements are most difficult to be approved by students because entrepreneurial status is still doubtful to be a profession with pride that is higher than other professions (formal sector workers) so that it is considered difficult to get a partner. 
Students are also still confined by the mindset that entrepreneurship is more interesting to do with conventional methods rather than online. This is certainly very contradictory to their scientific background which is closely related to the use of online media so that it is deemed necessary to provide knowledge and increase insight into the benefits of using online media as a means of supporting entrepreneurs. The last is the low level of business intuition or entrepreneurial talent possessed by students which means that it is still very necessary to provide information that is able to attract students to start entrepreneurs such as through research, learning, examples of successful young entrepreneurs as a driver to grow and train entrepreneurial intuition and talent.

\section{References}

[1] M. Rodrigues and M. Franco, "Composite Index to Measure Cities' Creative Performance: An Empirical Study in the Portuguese Context," Sustainability, vol. 11, no. 3, p. 774, Feb. 2019.

[2] K. P. Mark, J. C. H. So, V. C. W. Chan, G. W. T. Luk, and W. T. Ho, "Surviving in the Gig Economy: Change of STEM Students' Perceptions on the Generic Skills for the Workplace," in 2018 IEEE International Conference on Teaching, Assessment, and Learning for Engineering (TALE), 2018, no. December, pp. 1085-1090.

[3] I. Hernández Arteaga, C. Pérez Muñoz, and S. Rua Castañeda, "Intereses y perspectivas formativas en economía social y solidaria de los estudiantes universitarios," CIRIEC-España, Rev. Econ. pública, Soc. y Coop., no. 94, p. 91, Dec. 2018.

[4] B. Sumintono, "Rasch Model Measurements as Tools in Assesment for Learning," in Proceedings of the 1st International Conference on Education Innovation (ICEI 2017), 2018.

[5] G. Creeber, "Hideously White," Telev. New Media, vol. 5, no. 1, pp. 27-39, Feb. 2004.

[6] M. K. O. Lee and E. Turban, "A Trust Model for Consumer Internet Shopping," Int. J. Electron. Commer., vol. 6, no. 1, pp. 75-91, Sep. 2001.

[7] G. Shirokova, O. Osiyevskyy, and K. Bogatyreva, "Exploring the intention-behavior link in student entrepreneurship: Moderating effects of individual and environmental characteristics," Eur. Manag. J., vol. 34, no. 4, pp. 386-399, Aug. 2016.

[8] D. Veselá and K. Klimová, "Knowledge-based Economy vs. Creative Economy," Procedia - Soc. Behav. Sci., vol. 141, pp. 413-417, Aug. 2014.

[9] G. Evans, "Creative Cities, Creative Spaces and Urban Policy," Urban Stud., vol. 46, no. 5-6, pp. 1003-1040, May 2009.

[10] B. Setiawan, M. Panduwangi, and B. Sumintono, "A Rasch analysis of the community's preference for different attributes of Islamic banks in Indonesia," Int. J. Soc. Econ., vol. 45, no. 12, pp. 1647-1662, Dec. 2018.

[11] B. Sumintono, N. B. Subekti, N. Mislan, H. Said, and L. Mohd Tahir, "In Search of the Excellent School: A Case Study of an Indonesian International Standard School in Improving Its Capacity Building," Asia-Pacific Educ. Res., vol. 23, no. 3, pp. 565-576, 2014.

[12] S. W. Chan, Z. Ismail, and B. Sumintono, "A Framework for Assessing High School Students' Statistical Reasoning,” PLoS One, vol. 11, no. 11, p. e0163846, Nov. 2016. 